\title{
EDUCATION
}

\section{From Technical Assistants to Critical Thinkers: The Journey to World War II}

\section{MICHELLE BUTINA, ELIZABETH KENIMER LEIBACH}

\begin{abstract}
A review of professional literature was conducted to examine the history of the education of medical laboratory practitioners. This comprehensive review included historical educational milestones from the birth of medical technology to the advent of World War II. During this time period standards were developed by clinical pathologists for laboratory personnel and training programs. In addition, a formal educational model began to form and by the 1940's two years of college was required for matriculation into a medical technology program. Intertwined within the educational milestones are imprints of the evolution of critical thinking requirements and skills within the profession. For the first laboratory practitioners, critical thinking was not developed, discussed, or encouraged as duties were primarily repetitive promoting psychomotor skills.
\end{abstract}

ABBREVIATIONS: American Medical Association (AMA); American Medical Technologists (AMT), American Society of Clinical Pathologists (ASCP), Board of Registry (BOR), critical thinking (CT); doctor of medicine (M.D.), laboratory technician (LT), medical technologist (MT), World War I (WWI).

INDEX TERMS: Board of Registry, clinical pathologist, critical thinking, curriculum, education, history, training program

\section{Clin Lab Sci 2014;27(4):204}

Michelle Butina, Ph.D., MLS(ASCP) ${ }^{C M}$, Medical Laboratory Science, University of Kentucky, College of Health Sciences, Lexington, $K Y$

Elizabeth Leibach, Ed.D., MLS ${ }^{C M}, S B B^{C M}$, Principal Officer, HMES, Augusta, GA

Address for Correspondence: Michelle Butina, Ph.D., MLS $(\boldsymbol{A S C P})^{C M}$, Assistant Professor and Program
Director, Medical Laboratory Science University of Kentucky, College of Health Sciences, 900 South Limestone Street, CTW Bldg. Rm. 126E, Lexington, KY 405360200, (859)218-0852 Michelle.Butina@uky.edu

\section{FROM TECHNICAL ASSISTANTS TO CRITICAL THINKERS}

"There is no future without the past. In order to discuss the problems of the future intelligently, the accomplishments of the past may well be considered first. Therefore, to appreciate what may be in store for the future of medical technology, it seems logical to dwell briefly upon the record of what has been attempted and accomplished during the earlier years."

Dr. Kano Ikeda, opening keynote address, American Society of Medical Technologists, $1946^{1}$

\section{INTRODUCTION}

It has been more than a decade since there has been an article dedicated to the history of the profession in Clinical Laboratory Science; few of those appearing have addressed the history of medical laboratory science educational curriculum and programs. The article that follows attempts to highlight the educational milestones the medical laboratory science profession has experienced, from the 1890's-1930's, with an emphasis on the emergence of critical thinking skills in medical laboratory science practice.

\section{What is critical thinking (CT)?}

For decades CT has been studied in multiple disciplines and as such it has innumerable definitions and concepts. For this article, CT can be defined as "the intellectually disciplined process of actively and skillfully conceptualizing, applying, analyzing, synthesizing, and/or evaluating information gathered from, or generated by, observation, experience, reflection, reasoning, or communication, as a guide to belief and action". 2

Similar to the many definitions there are numerous CT synonyms and components. Clinical reasoning, clinical decision making, and clinical judgment are just a few of the terms often used to describe CT. ${ }^{3,4}$ Components of 
CT often include: reflective thinking, analysis, judgment, inference, deduction, interpretation, and synthesis. ${ }^{3,5}$ The characteristics of a critical thinker include: inquisitive, truth-seeking, analytical, systematic, open-minded, and self-confident. ${ }^{5}$ The appearance and depth of these characteristics describe six CT stages summarized in Table $1 .^{6}$ The notion is that CT characteristics begin to appear at Stage 3 (beginning thinker) with depth of thinking or additional CT characteristics being employed and observed at subsequent developmental stages.

Table 1. Six incremental stages to the development of critical thinking.

\begin{tabular}{ll}
\hline Stage & \multicolumn{1}{c}{ Description } \\
\hline Unrefelective Thinker & $\begin{array}{l}\text { Unaware of significant problems in life } \\
\text { due to poor thinking } \\
\text { Aware that significant problems come } \\
\text { from poor thinking } \\
\text { Tries to modify thinking but lacks } \\
\text { Beginning Thinker }\end{array}$ \\
Practicing Thinker & $\begin{array}{l}\text { Regularly assesses/analyzes thinking for } \\
\text { clarity, accuracy, relevance, logicalness, etc. } \\
\text { Committed lifelong practice of thinking } \\
\text { analysis while trying to advance it }\end{array}$ \\
Advanced Thinker & $\begin{array}{l}\text { CT and practical insight is highly } \\
\text { intuitive }\end{array}$
\end{tabular}

Adapted from The Miniature Guide to Critical Thinking Concepts and Tools by Dr. Richard Paul and Dr. Linda Elder.

Critical thinking is an imperative skill for all health care professionals as it will ensure they can adapt and meet the demands of their rapidly changing work environment. $^{7}$ Promotion of CT in health care professional programs is critical to ensure they are competent in their role and as such educators throughout healthcare are being challenged to develop curriculum to foster development of CT skills in students. ${ }^{3}$ Many allied health professions (e.g., nursing and physical therapy) are being required by their accrediting bodies or professional societies to develop and assess students CT skills in order to produce a graduate who possesses the ability to make sound clinical decisions. ${ }^{3,4}$

In medical laboratory science, seven critical thinking practice themes have been identified: 1) acting professionally, 2) developing expertise, 3) managing tasks 4) managing time, 5) reasoning technologically, 6) reflecting on tasks, and 7) using experience. These seven behavior or practice themes were derived from 25 prominent CT behaviors observed in medical laboratory science practice and represent all learning orientations, i.e., cognitivist (32\%), behaviorist (24\%), humanist/affective (20\%), and situated/contextual $(24 \%){ }^{8}$ As the focus in practice shifts from monitoring analytic efficacy to include measures of quality in pre and post-analytic parameters CT development in all learning orientations is going to be imperative.

\section{HISTORICAL PERSPECTIVES}

Prior to 1900, laboratory testing, consisting of rudimentary procedures such as hemoglobin estimation, manual cell counts, simple urinalysis, and examination of sputum for tuberculosis, was often performed by the physician in their home or office. Clinical laboratories were only found in public health departments and teaching hospitals with hospital physicians performing testing procedures. ${ }^{9,10}$

By the start of the twentieth century epidemic outbreaks of diphtheria, pneumonia, poliomyelitis, typhoid, and tuberculosis stimulated the development of testing and new drugs. ${ }^{11}$ Commercial and reference laboratories were established to support the burgeoning diagnostics market. ${ }^{9}$ By the start of World War I (WWI), the majority of laboratory testing was performed by bacteriologists, biochemists, or laboratory physicians (soon to be known as clinical pathologists). By the end of WWI female assistants were being hired to assist the nascent workforce. ${ }^{12}$

As testing facilities and menus increased, the United States experienced its first shortage of laboratory personnel. ${ }^{13}$ In 1916, Pennsylvania passed state law requiring hospitals to have an adequate laboratory staffed with a laboratory technician(s).$^{14}$ In 1918, John A. Kolmer, M.D., Director of the Philadelphia Polyclinic, claimed that "the systematic training of properly prepared young women in laboratory methods" was necessary to meet the shortage in civilian and armed forces facilities nationwide. ${ }^{15}$ Subsequently, one of the first technical training programs for laboratory technicians was established in the Department of Pathology and Bacteriology at the Philadelphia Polyclinic. The program had an introductory course for high school graduates (e.g., trained in the making of media, making and staining sections of tissue, and sterilizing glassware) and an 


\section{EDUCATION}

advanced clinical pathology courses (e.g., trained in complement-fixation techniques). ${ }^{15}$ However no minimum educational requirements or training standards were established for the curriculum.

By 1920, physicians (often internists) who performed laboratory testing on their patients were considered clinical pathologists. ${ }^{16}$ Yet clinical pathologists were not recognized as a specialty by the American Medical Association (AMA). Thus in 1921 a group of clinical pathologists constructed a plan to form a national society, and a year later, the American Society of Clinical Pathologists (ASCP) was formed. ${ }^{14}$ In 1926, the American College of Surgeons set forth a standards program that required certified hospitals to have a clinical laboratory for bacteriological, chemical, hematological and serological testing, and histological examination of tissue. ${ }^{1}$

Implementation of this facility-based standard exacerbated the need for qualified personnel to perform laboratory procedures and testing, and numerous training programs were established. Yet because education standards had not been formulated, training programs varied widely in admission, content, and length. In 1940, Dr. Kano Ikeda (Secretary and later Chair of the Committee on the Registration of Technicians and founding member of Board of Registry) described the variety of laboratory technician qualifications and training, of the early years, as a situation of "utter confusion" that became "one of the great stumbling blocks in the path of healthy progress of clinical pathology". ${ }^{17}$ The typical laboratory technician was female and subordinate to the pathologist, who was most frequently male. As reported at the time, pathologists customarily hired women as their salaries were low and they would not challenge the authority of the pathologist. ${ }^{12}$ Dr. F. W. Sunderman, (Founding Fellow of College of American Pathologists and past President of the American Society of Clinical Pathologists) in 1942, explained that laboratory technicians followed established principles of ethics, "not to divulge the results of analyses, not to diagnose, interpret or prescribe" as this was the role of the pathologist. ${ }^{13}$

Once pathologists organized as a medical specialty, they acknowledged the need for "technical assistants" who were adequately trained. ${ }^{5}$ Granted not all pathologists agreed to the notion of standardizing the qualifications and training of laboratory technicians. The common objections included fears that: 1) workers would unionize for economic gain, resulting in 2) services being more costly, and 3) additional education would lead to displacement of the role of clinical pathologists. The prevalent thought was that detailed scientific knowledge is not required for workers performing only mechanical procedures. ${ }^{18}$

Despite prevalent disinterest, and some frank opposition, the ASCP spearheaded an effort to set educational standards and to certify/register those meeting these criteria. In 1926, a "Committee on the Registration of Technicians" was formed within ASCP to create a registry for competent laboratory personnel. ${ }^{17}$ In 1928, this internal ASCP committee became the "Board of Registry of Laboratory Technicians" (BOR) whose functions were to establish minimum standards for laboratory professionals, register those who met the standards (granting them a certificate of registration), and approve programs offering acceptable laboratory training. ${ }^{17}$ The newly formed BOR focused its efforts first on setting standards for registration, quite minimal at the time, and would then transition to establishing standards for acceptable laboratory training programs. ${ }^{16}$

The BOR allowed applicants to apply but did not register anyone until 1930. This allowed for the collection of data on those applying (350 applications) including task analysis in order to define practice levels. Out of the 350 applications, the majority of the applicants were female, between the ages of 20 and 29, and high school graduates. ${ }^{17}$

Initially, two categories of laboratory workers were established, Medical Technologists (MTs) and Laboratory Technicians (LTs). ${ }^{17}$ The MT would have a college or university degree, one full year of practical experience in a laboratory (accomplished via the training school), and sponsorship by a pathologist. Individuals meeting criteria were approved for registration and elected to the BOR at the annual ASCP meeting. The LT would have a high school diploma, one year of college work to include chemistry and biology and six months of practical experience. The LT designation for this category was eliminated in 1936 (effective in 1938); registered technicians there forth were known as medical technologists. ${ }^{14,17}$ (Two 
designations were no longer needed, due to the educational standards set in 1933 and discussed below, thus the current preferred designation was retained). Admission to the registry from 1928-1932 required appropriate training and recommendations; no certifying examinations were required. ${ }^{19}$

In 1930, the BOR distributed surveys to administrators of training programs offering at least one course focused on the training of laboratory practitioners (either LT or MT); administrators from 137 programs responded. From these responses, the BOR found that the training of laboratory practitioners occurred in a variety of settings; the majority was hospital laboratories and others consisted of colleges/universities, private laboratories, commercial programs, and public health laboratories. Additional survey results indicated that the majority of training programs only required a high school diploma for entrance into their program, and the length of the courses varied greatly. Though the majority provided formal lectures or informal talks, $38 \%$ of respondents did not offer either. ${ }^{20}$

From the survey results, the BOR moved forward with setting educational standards for programs in 1933. Summarizing in chronological order, the BOR established minimum standards for approved (accredited) programs and set the prerequisite of one year of college before matriculation. ${ }^{14}$ For practitioners, the BOR implemented a certification exam that included written (essay) and practical components in addition to the academic requirements previously made. ${ }^{17}$

After the initial program approvals, the BOR decided not to approve commercial training programs. . Many pathologists felt that these private schools, numerous at the time, fell short of the standards established by the BOR with (inadequate teaching facilities, poorly trained instructors, and admission requirements based on financial commitment rather than academic standards). In response, the commercial programs established their own accreditation board, registry and certifying exam, and professional organization, in 1939, the American Medical Technologists (AMT). ${ }^{17,19-21}$

In 1936, the BOR again surveyed training programs for laboratory practitioners. As before, the majority of training programs were found in hospital laboratory departments in which students were admitted after 1-4 years of college. In contrast, programs in colleges and universities often consisted of 3-4 years of liberal arts, sciences, and laboratory course(s) with a fourth or fifth year of instruction occurring in an affiliated hospital laboratory. Based on these findings, the BOR established essential standards for approved programs which included quality criteria for organization, faculty, clinical facilities, curriculum, and ethics. Approved in 1934 and begun in 1938, the college prerequisite for entrance into a medical technology program was raised from one year to two years of college, including major sciences, prior to entering an approved program. ${ }^{19}$ The requirement of one year of practical experience in a hospital laboratory was continued. ${ }^{22}$

Even though the BOR increased educational requirements during the 1930 's, significant numbers of pathologists espoused the training of laboratory practitioners to be mechanical and repetitious requiring little knowledge or thinking. ${ }^{23}$ Critical thinking (CT) was still not a skill set that was promoted and, if anything, it was discouraged considered unnecessary for performing mechanical procedures. Sunderman (1942) states, "The clinical pathologist accepts the responsibility for interpreting the results and working out the details of the analysis to be done; the medical technologist, as an aide to the clinical pathologist, faithfully carries out these details and reports to the clinical pathologist...the medical technologist...is obligated to seek help from him in the solution of any laboratory problem that may be presented". ${ }^{13}$

This is not to say that these laboratory practitioners were not thinking critically in their role but it was not taught in any of the training programs, or discussed in the workplace let alone encouraged or promoted. Critical thinking behaviors/skills of practicing laboratory practitioners were primarily behaviorist (psychomotor learning). With innovation and the rapid development of diagnostic testing procedures the majority of affective (attitudinal), cognitive, and contextual/situated skills remained within the purview of the clinical pathologist. Laboratory practitioners themselves had not responded to the need for educational standards in training programs. Collectively, they had not recognized a body of knowledge to be systematically transmitted for the future. 


\section{CONCLUSION}

Medical technology became a profession with the advent of registration in 1930. Though educational requirements continued to increase as laboratory medicine expanded through the 1930's, those requirements have changed minimally since that time. (Table 2) In 1931, Dr. Ikeda claimed that "The ultimate aim of the Board is to get as many as possible of the universities and colleges to include in their regular curricula a course in Medical Technology either as a four-year course leading to a degree or on a twoyear certificate plan. These courses must always be in affiliation with recognized general hospitals where the students shall obtain a part of the practical training as an 'interne' or apprentice". ${ }^{20}$ Essentially, the Ikeda model, proposed in 1931, is still in place today.

Table 2. Major historical milestones from 1900 to 1939.

\begin{tabular}{|c|c|}
\hline \multicolumn{2}{|l|}{ By } \\
\hline 1918 & $\begin{array}{l}\text { Women are hired as assistants in hospital } \\
\text { laboratories. }{ }^{12}\end{array}$ \\
\hline 1922 & $\begin{array}{l}\text { The American Society of Clinical Pathologists is } \\
\text { established. }{ }^{14}\end{array}$ \\
\hline 1928 & $\begin{array}{l}\text { "Board of Registry of Laboratory Technicians" is } \\
\text { established. }{ }^{17}\end{array}$ \\
\hline 1930 & $\begin{array}{l}\text { First medical technologists are registered with the } \\
\text { Board of Registry. }{ }^{17}\end{array}$ \\
\hline 1933 & $\begin{array}{l}\text { One year of college is required prior to entering an } \\
\text { approved program/school. }{ }^{14}\end{array}$ \\
\hline & $\begin{array}{l}\text { Applicants are now required to pass certification } \\
\text { examination that included practical and written } \\
\text { components. }{ }^{17}\end{array}$ \\
\hline 1938 & $\begin{array}{l}\text { Two years of college is required prior to entering an } \\
\text { approved program/school. }{ }^{19}\end{array}$ \\
\hline
\end{tabular}

A companion article will chronicle our professional evolution from the 1940 's to present day. With the advent of World War II, diagnostic breakthroughs and novel medical research initiated unprecedented advances in medicine that will begin to stress the newly formed educational model. ${ }^{24}$ Although only minor modifications were made to the educational model throughout the second half of the $20^{\text {th }}$ century, the profession evolved by leaps and bounds. These two articles will challenge you to consider the answer to the question foremost in our professional psyche: has our profession evolved adequately to meet health services delivery needs in the $21^{\text {st }}$ century?

\section{REFERENCES}

1. Ikeda K. The future of medical technology. Am J Med Tech
1946;12:146-55.

2. Paul RW. Critical Thanking Handbook: Basic Theory and Instructional Structures. Santa Rosa CA: Foundation for Critical Thinking; 2000.

3. Brudvig TJ, Dirkes A, Dutta P, Rane K. Critical thinking skills in health care professional students: A systematic review. J Phys Ther Educ 2013;27(3):12-25.

4. Huhn K, Black L, Jensen GM, Deutsch JE. Tracking change in critical-thinking skills. J Phys Ther Educ 2013;27(3):26-31.

5. Banning M. Nursing research: Perspectives on critical thinking. Br J Nurs 2006;15(8):458-61.

6. Paul R, Elder L. The Miniature Guide to Critical Thinking: Concepts and Tools. Santa Rosa CA: Foundation for Critical Thinking; 2009.

7. Kenimer EA. The identification and description of critical thinking behaviors in the practice of clinical laboratory science, part 1: Design, implementation, and evaluation of a national survey. J Allied Health 2002;31(2):56-63.

8. Leibach EK. Grounded theory in medical laboratory science expert practice development. Clin Lab Sci 2011;24(4):37-44.

9. Kotlarz VR. Tracing our roots: Origins of clinical laboratory science. Clin Lab Sci 1998;11(1):5-7.

10. Berger D. A brief history of medical diagnosis and the birth of the clinical laboratory. Part 1: Ancient times through the $19^{\text {th }}$ century. Med Lab Obs 1999;31(7)28-40.

11. Berger, D. A brief history of medical diagnosis and the birth of the clinical laboratory. Part 2: Laboratory science and professional certification in the $20^{\text {th }}$ century. Med Lab Obs 1999;31(8):32-8.

12. Kotlarz VR. Tracing our roots: The first clinical laboratory scientist. Clin Lab Med 1998;11(2):97-100.

13. Sunderman FW. Opportunities and responsibilities in medical technology. Am J Med Tech 1942;8:130-5.

14. Montgomery LG. A short history of the registry of medical technologists of the American Society of Clinical Pathologists. Am J Clin Path 1970;53:433-46.

15. Kolmer JA. The demand for and training of laboratory technicians. Bost Med \& Surg J 1918;178(18)610.

16. Rodriquez FH, Ball JR. The American Society for Clinical Pathology: The pathology society of "firsts". Lab Med 2007;38(10):595-601.

17. Ikeda K. Twelve years of registry and its contribution to medical technology. Am J Med Tech 1940;6:222-34.

18. Ikeda K. Specialization in medical technology. Am J Med Tech 1944;10(5):159-64.

19. Ikeda K. Survey of schools for clinical technicians. Am J Med Tech 1936;2:198-206.

20. Ikeda K. Survey of training schools for laboratory technicians. Am J Clin Path 1931;1:467-76.

21. Kotlarz VR. Tracing our roots: Progress in advancing the profession (1945-62). Clin Lab Sci 1999;12(2):91-7.

22. Arnold JG. Current educational standards in medical technology. Am J Med Tech 1960;26:101-10.

23. Arens MA. Medical technology-education problems. Am J Med Tech 1955;21:65-74.

24. Andrus EC, Keefer CS, Richards AN. (eds.) Advances in military medicine. vol 1. Chicago: Little, Brown \& Company; 1948. 